
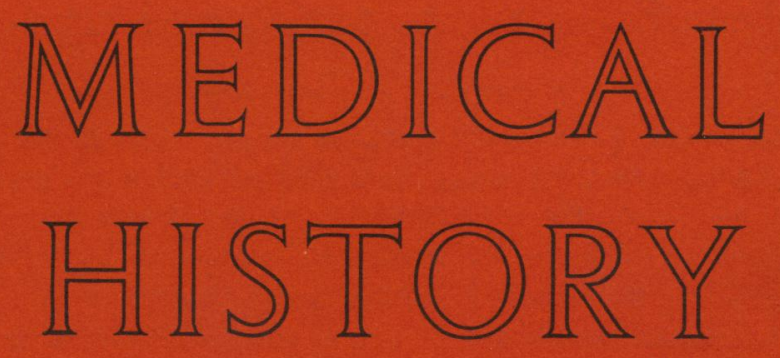

A QUARTERLY JOURNAL

DEVOTED TO THE HISTORY AND BIBLIOGRAPHY OF MEDIGINE AND THE RELATED SGIENGES

\title{
Volume IV Number 2
}

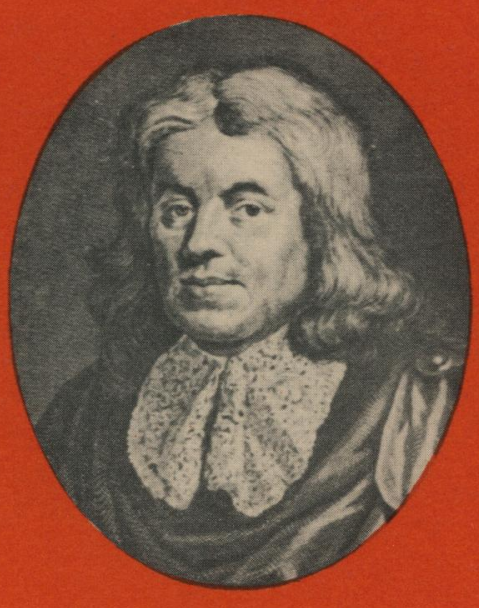

APRIL I 960

WM DAWSON \& SONS LTD

I6 West Street, Farnham, Surrey 


\section{CONTENTS}

Volume IV

APRIL I96o

Number 2

\section{Main Articles}

MEDIGINE-MOTHER OF THE SGIENGES

C. E. RAVEN

Page 85

MEDIGAL RECORDS OF DARTMOUTH, I 425-I887

R. M. S. MCGONAGHEY

Page 91

THE LIFE AND WORKS OF GUILHELMUS FABRIGIUS HILDANUS

$$
\text { ( I } 560-1634)
$$

PART I

ELLIS JONES

Page 112

THE NATURAL HISTORY OF INSENSIBLE PERSPIRATION

$$
\begin{aligned}
& \text { E. T. RENBOURN } \\
& \text { Page } 135 \\
& \text { JOHN BRAXTON HICKS（I 823-I 897) } \\
& \text { J. H. YOUNG } \\
& \text { Page } 153
\end{aligned}
$$

Scottish Society of the History of Medicine; Faculty of the History of Medicine and Pharmacy, Society of Apothecaries of London. 


\section{Medical History}

\section{A QUARTERLY JOURNAL}

DEVOTED TO THE HISTORY AND BIBLIOGRAPHY OF MEDIGINE AND THE RELATED SGIENGES

OFFIGIAL ORGAN OF

THE GAMBRIDGE UNIVERSITY HISTORY OF MEDIGINE SOGIETY FAGULTY OF THE HISTORY OF MEDIGINE AND PHARMAGY. THE WORSHIPFUL SOGIETY OF APOTHEGARIES OF LONDON

THE NORWEGIAN SOGIETY FOR THE HISTORY OF MEDIGINE THE OSLER GLUB OF LONDON THE SGOTTISH SOGIETY OF THE HISTORY OF MEDIGINE

Editor: W. J. Bishop

\section{NOTICE TO CONTRIBUTORS}

Contributions, which may deal with any aspect of medical history or bibliography, are invited. The maximum length for original articles is about 10,000 words. Previously unpublished texts and documents, short papers, and bibliographical notes and queries will also be welcomed.

Manuscripts should be typewritten with double spacing and wide margins. The Editor reserves the right to make literary corrections. Captions or legends of illustrations should include particulars of their source and should be typed on a separate sheet. No particular style of bibliographical citation is insisted upon, but contributors are asked to pay special attention to the accuracy of their references.

A galley proof, which should be corrected and returned to the Editor as quickly as possible, will be sent to every contributor of an original article.

Contributors will receive fifty reprints free of cost. Particulars of the cost of additional reprints will be sent with galley proofs.

Manuscripts, review copies of books and reprints, and correspondence relating to the publication of papers should be addressed to the Editor, Medical History, c/o William Dawson \& Sons Ltd., I6 West Street, Farnham, Surrey.

\section{SUBSCRIPTIONS}

Medical History is published quarterly on the Ist January, April, July and October.

The subscription rate is $£ 2$ Ios. od. a year in the United Kingdom, and $\$ 7.50$ in Canada and the U.S.A. Single issues of the current volume can be purchased at ${ }_{5} 5$. each, and of previous volumes at $20 s$. each.

All subscriptions and orders should be addressed to William Dawson \& Sons Ltd., Cannon House, Macklin Street, London, W.C.2.

All inquiries regarding advertising should be addressed to William Dawson \& Sons Ltd., I6 West Street, Farnham, Surrey. 


\section{OUR COVER DESIGN}

The portrait of Thomas Sydenham reproduced on the front cover is taken from the painting ascribed to Sir Peter Lely and engraved by J. Houbraken for Thomas Birch's The Heads and Characters of Illustrious Persons of Great Britain, I 743-5I. 